\title{
CHEMICAL AND BIOLOGICAL SEED TREATMENT AND THEIR EFFECT ON SOYBEAN DEVELOPMENT AND YIELD ${ }^{1}$
}

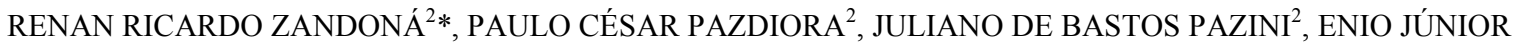 \\ SEIDEL $^{3}$, LUCIANA ZAGO ETHUR ${ }^{2}$
}

\begin{abstract}
In the search for homogeneous planting density and satisfactory results in soybean development and yield, the treatment of seeds can be carried out using a combination of chemical fungicides, growth stimulators, and other biological agents. The objective of this study is to evaluate the effect of chemical and biological inputs for soybean seed treatment on crop development and yield. Experiments were carried out in the 2010/2011 growing season in three municipalities of Rio Grande do Sul using the following treatments: fungicide fludioxonil, Trichoderma spp., fludioxonil + Trichoderma spp., fludioxonil + Trichoderma spp. + the growth stimulator Biozyme ${ }^{\circledR}$, and a control (untreated). The total number of pods in treatment with Trichoderma spp. and the other treatments were up to $77 \%$ higher than that of the control. The grain yield of treatments with fludioxonil, fludioxonil + Trichoderma spp., and fludioxonil + Trichoderma spp. + Biozyme $^{\circledR}$ was up to $14 \%$ higher than that of the control. These results indicate that fludioxonil combined with the fungus Trichoderma spp. and Biozyme ${ }^{\circledR}$ is indicated for treating soybean seeds and increases crop development and grain yield.
\end{abstract}

Keywords: Glycine max. Plant growth. Trichoderma spp.

\section{INSUMOS QUÍMICO E BIOLÓGICO NO TRATAMENTO DE SEMENTES E SUA INTERFERÊNCIA NO DESENVOLVIMENTO E PRODUÇÃO DE SOJA}

RESUMO - Na busca por estande de plantas homogêneo e resultados satisfatórios no desenvolvimento e produção de soja, pode ser realizado o tratamento de sementes combinando fungicidas químicos, bioestimuladores e outros produtos biológicos. Dessa forma, objetivou-se avaliar a interferência de insumos químico e biológico em tratamento de sementes no desenvolvimento e produção de soja. Para isso, foram conduzidos experimentos no ano agrícola 2010/2011 em três localidades do Rio Grande do Sul, utilizando-se os seguintes tratamentos de sementes: fungicida fludioxonil; Trichoderma spp.; fludioxonil + Trichoderma spp.; fludioxonil + Trichoderma spp. + Biozyme $^{\circledR}$; e testemunha (sem tratamento). Para o número total de vagens, o tratamento com Trichoderma spp. e os demais tratamentos conjugados apresentaram até $77 \%$ mais vagens do que a testemunha. Os tratamentos fungicida fludioxonil, fungicida fludioxonil + Trichoderma spp. e fungicida fludioxonil + Trichoderma spp. + Biozyme $^{\circledR}$ apresentaram até $14 \%$ maior produtividade do que a testemunha. $\mathrm{O}$ fungicida fludioxonil foi indicado para tratamento de sementes de soja conjugado com o fungo Trichoderma spp. e o bioestimulador Biozyme ${ }^{\circledR}$, por promoverem o desenvolvimento de plantas e o aumento da produtividade de soja.

Palavras-chave: Glycine max. Crescimento de plantas. Trichoderma spp.

\footnotetext{
${ }^{*}$ Corresponding author

${ }^{1}$ Received for publication in $03 / 19 / 2018$; accepted in 02/10/2019.

Paper extracted from the research project.

${ }^{2}$ Universidade Federal do Pampa, Itaqui, RS, Brazil; renan zandona@hotmail.com - ORCID: 0000-0003-2429-8254, paulo.pazdiora@yahoo.com.br - ORCID: 0000-0001-6996-9619, julianopazzini@hotmail.com - ORCID: 0000-0002-4350-1708, luethur@gmail.com - 0000-0001-6664-8326.

${ }^{3}$ Department of Statistics, Center of Natural and Exact Sciences, Universidade Federal de Santa Maria, Santa Maria, RS, Brazil; enioseidel@gmail.com - ORCID: 0000-0002-9656-0699.
} 


\section{INTRODUCTION}

Soybean is the most important crop in Brazilian agribusiness, which is the basis of the primary sector economy and trade balance in Brazil. Brazil is the world's second largest producer and exporter of grains, and the state of Rio Grande do Sul accounts for $16 \%$ of the national production, with an average of 3,013 $\mathrm{kg} \mathrm{ha}^{-1}$ (CONAB, 2019).

In the search for homogenous plant density and satisfactory results in soybean development and grain yield, other crop protection products, and growth stimulators are used in conjunction with fungicides in seed treatment. Seed treatment with fungicides is considered essential for managing seedborne pathogens and soil-borne fungi, which can cause seed rot and seedling damping-off (HENNING et al., 2010).

Integrated disease management using biological control agents such as antagonistic fungi combined with chemical fungicides can be effective to control pathogens and reduce the use of pesticides (PANDOLFO, 2007). Mertz, Henning and Zimmer (2009) reported that several bioprotective agents are being commercialized and recommended for treating soybean seeds. However, there is limited research on seed treatment with biological fungicides.

At present, formulations based on Trichoderma spp. are being used to treat soybean seeds, and the fungus acts as an antagonist to the pathogens present in the seeds or soil and as a plant growth stimulator. Trichoderma spp. are antagonistic fungi widely used in the biological control of pathogenic fungi (MACHADO et al., 2012) and seed treatment (ETHUR et al., 2005; MASTOURI;
BJÖRKMAN; HARMAN, 2010) against a wide range of disease-causing pathogens in different cultures. In addition, this fungus stimulates plant growth and development (HARMAN et al., 2004). In this respect, the TA1 isolate of Trichoderma asperellum promoted an increase in shoot development in cucumber (ETHUR et al., 2012), and an isolate of $T$. harzianum increased the number of pods per plant and grain yield in soybean (GÖRGEN et al., 2009).

The objective of this study is to evaluate the use of chemical and biological inputs in soybean seed treatment and their effect on crop development and yield.

\section{MATERIAL AND METHODS}

The field experiments were conducted in three municipalities during the 2010/2011 growing

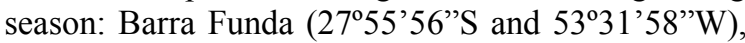
with typical Dystrophic Red Latosol; Cândido Godói (27'93'13.72”S and 5471'20.04'W), with Eutrophic Red Nitosol; and Tupanciretã $\left(29^{\circ}\right.$ 07'012'S and 53 57'56.8'W), with Dystrophic Yellow Red Argisol (EMBRAPA, 2013), in soybean -producing regions 102 and 101, respectively, in Rio Grande do Sul, Brazil (KASTER; FARIAS, 2011). According to the classification of Köppen-Geiger, the climate of the region is type Cfa, subtropical humid with hot summers and without a defined dry season. Data on rainfall, air temperature, and relative air humidity in these municipalities from October 2010 to March 2011 are presented in Figure 1.

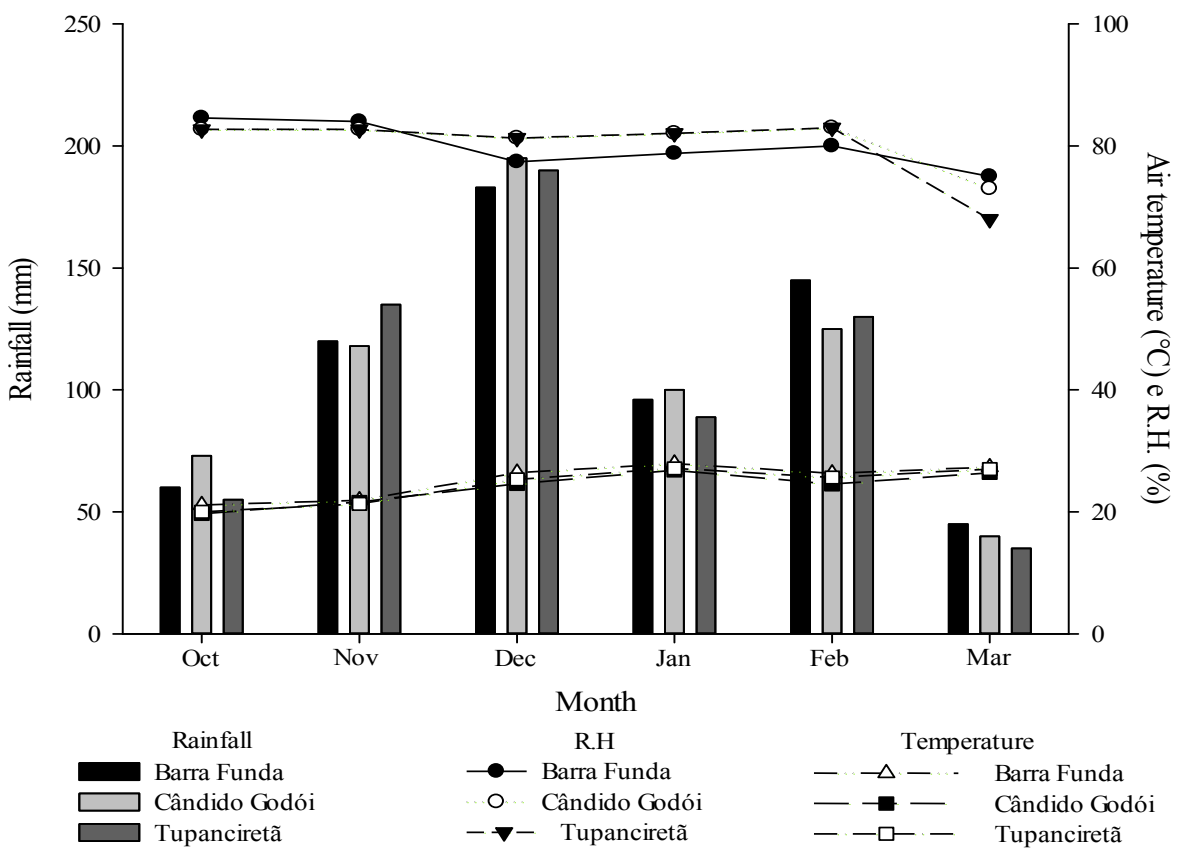

Figure 1. Rainfall accumulation $(\mathrm{mm})$, mean temperature $\left({ }^{\circ} \mathrm{C}\right)$, and relative air humidity $(\mathrm{RH} \%)$ in the study period in the 2010/2011 growing season in the municipalities of Barra Funda, Cândido Godói, and Tupanciretã, Rio Grande do Sul, Brazil. 
The study used a completed randomized block design, with five treatments and four replications. The experiments were organized in four blocks of $25.00 \times 2.25 \mathrm{~m}$, each block consisting of five plots of $5.00 \times 2.25 \mathrm{~m}\left(11.25 \mathrm{~m}^{2}\right)$, and each plot consisting of five rows spaced at $0.45 \mathrm{~m}$.

The fungicide fludioxonil (phenylpyrrole) in combination with Trichoderma spp. was used for treating soybean seeds. This fungicide was selected because it has been shown to promote $100 \%$ fungal survival in the seed treatment tests (PAZINI et al., 2013). The Trichoderma spp. isolate T2 was obtained from the sclerotia of Sclerotinia sclerotiorum, which were used as baits in the soil of Itaqui, Rio Grande do Sul. The Trichoderma spp. powdered formulation was obtained as described by Ethur et al. (2005). Before seed treatment, the viability of Trichoderma spp. was assessed by germination in Petri dishes containing potato dextrose agar medium.

The chemical treatment of soybean cultivar NS6411RR was carried out manually in plastic bags one day before sowing. One of the treatments contained Biozyme $^{\circledR}$ (Arysta Lifescience do Brazil Indústria Química e Agropecuária SA, Salto de Pirapora, SP, Brazil), which is a mixed mineral fertilizer $\left(\mathrm{N}, \mathrm{K}_{2} \mathrm{O}, \mathrm{B}, \mathrm{Fe}, \mathrm{Mn}, \mathrm{S}, \mathrm{Zn}\right.$, and total organic carbon), and was applied on seeds and leaves in the proportion of $2 \mathrm{~mL}^{-1} \mathrm{~kg}$ of seed.

Treatment with Trichoderma spp. was performed at the time of sowing, and the fungus was mixed to the seeds in the proportion of $600 \mathrm{~g}$ of powder to $100 \mathrm{~kg}$ of seeds. Therefore, the seed treatments used in the three localities were: $\mathrm{T} 1$, control (untreated seeds); T2, 0.435 g Trichoderma spp.; T3, $0.087 \mathrm{~mL}$ fludioxonil $+0.435 \mathrm{~mL}$ water; $\mathrm{T} 4,0.087 \mathrm{~mL}$ fludioxonil $+0.435 \mathrm{~mL}$ water +0.435 g Trichoderma spp.; T5, $0.087 \mathrm{~mL}$ fludioxonil + $0.435 \mathrm{~mL}$ water $+0.435 \mathrm{~g}$ Trichoderma spp. +0.174 mL Biozyme ${ }^{\circledR}$

The cultivation system used was no-tillage, and black oats (Avena strigosa) were cultivated in the winter in the three experimental areas. Black oats were desiccated 60 days after sowing (DAS), and fertilization at planting was $350 \mathrm{~kg} \mathrm{ha}^{-1}$ of the formulation 2-18-18 NPK. During the crop cycle, three fungicide applications and insect and weed control were performed according to the needs of each experimental area.

Plant height was measured in three central rows of each plot (area of $4.05 \mathrm{~m}^{2}$ ) at $30 \mathrm{DAS}$ (PH30DAS) and 60 DAS (PH60DAS). Other evaluated variables were the number of pods with one grain per plant (NP1G), number of pods with two grains per plant (NP2G), number of pods with three grains per plant (NP3G), number of pods per plant (NPP), number of filled grains (NFG), number of infected grains (NIG), thousand-grain mass (TGM), and grain yield per hectare (GY).

Only the variables PH30DAS, PH60DAS, NSG, NIG, TGM, and GY presented valid assumptions for analysis of variance. Therefore, the square root transformation was applied to NPP and NPOG, and the inverse transformation was applied to NPDG and NPTG. The data from the three municipalities were subjected to combined analysis. Analysis of variance was performed using the F-test, and the means were compared using the Scott-Knott test at a level of significance of 5\%. All analyses were performed using the software R (R DEVELOPMENT CORE TEAM, 2015)

\section{RESULTS AND DISCUSSION}

The interaction between seed treatment (ST) and each study area (SA) was significant only for PH30DAS and NPP (Tables 1 and 2), and therefore the isolated effect of each factor on the other variables was then evaluated. There were significant differences in NP2G, NFG, NIG and GY between treatments, and significant differences in PH60DAS, NP1G, NP2G, NP3G, NFG, TGM, and GY between the SAs (Table 1 and 2).

Table 1. Summary of the analysis of variance of plant height at 30 days after sowing [DAS] (PH30DAS), plant height at 60 DAS (PH60DAS), number of pods with one grain (NP1G), number of pods with two grains (NP2G), and number of pods with three grains (NP3G) in soybean seeds treated with chemical and biological inputs in the municipalities of Barra Funda, Cândido Godói, and Tupanciretã, Rio Grande do Sul, Brazil, in the 2010/2011 growing season.

\begin{tabular}{|c|c|c|c|c|c|c|c|c|c|c|c|}
\hline SV & DF & \multicolumn{10}{|c|}{ 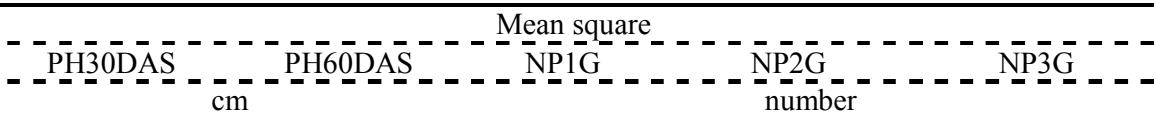 } \\
\hline$\overline{\text { ST }}$ & 4 & 15.00 & ns & 20.68 & ns & 0.25 & ns & 0.00014 & $*$ & 0.0002 & ns \\
\hline SA & 2 & 485.09 & * & 752.22 & $*$ & 5.01 & $*$ & 0.00064 & * & 0.0081 & $*$ \\
\hline $\mathrm{ST}^{*} \mathrm{SA}$ & 8 & 10.04 & * & 2.92 & ns & 0.36 & ns & 0.00006 & ns & 0.0001 & ns \\
\hline Block (SA) & 9 & 2.29 & ns & 8.30 & ns & 0.18 & ns & 0.00007 & ns & 0.0001 & ns \\
\hline Residual & 36 & 3.49 & & 14.39 & & 0.26 & & 0.00004 & & $\underline{0.0001}$ & \\
\hline $\bar{C} \bar{V}(\overline{0})$ & & $\overline{7.16}$ & & $\overline{4} . \overline{0}-\overline{-}$ & & $\overline{2} 2 . \overline{48}$ & & $\overline{23} .60$ & & $-\overline{4} . \overline{18}$ & \\
\hline
\end{tabular}

$\mathrm{SV}$, sources of variation; DF, degrees of freedom; CV, coefficient of variation; ST, seed treatment; SA, study areas (Barra Funda, Cândido Godói, and Tupanciretã); ${ }^{\text {ns }}$ non-significant; *significant at $\mathrm{p}<0.05$ using the F-test. 
Table 2. Summary of the analysis of variance of the number of pods per plant (NPP), number of filled grains (NFG), number of infected grains (NIG), thousand-grain mass (TGM), and grain yield (GY) of soybeans seeds treated with chemical and biological inputs in the municipalities of Barra Funda, Cândido Godói, and Tupanciretã, Rio Grande do Sul, Brazil, in the 2010/2011 growing season.

\begin{tabular}{|c|c|c|c|c|c|c|c|c|c|c|c|}
\hline \multirow[t]{2}{*}{ SV } & $\mathrm{DF}$ & \multicolumn{10}{|c|}{ 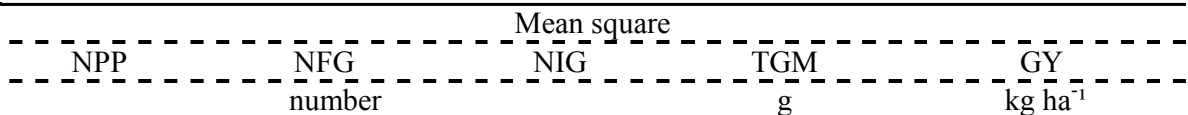 } \\
\hline & 4 & 2.87 & * & 636.36 & $*$ & 180.15 & $*$ & 11.02 & $\mathrm{~ns}$ & 383895.81 & $*$ \\
\hline SA & 2 & 66.68 & $*$ & 6823.95 & $*$ & 22.85 & ns & 967.70 & $*$ & 466542.60 & * \\
\hline $\mathrm{ST}^{*} \mathrm{SA}$ & 8 & 2.33 & $*$ & 52.91 & ns & 10.85 & ns & 14.40 & ns & 76023.12 & ns \\
\hline Block (SA) & 9 & 0.99 & ns & 46.02 & ns & 6.84 & ns & 11.05 & ns & 101312.23 & ns \\
\hline Residual & & $\frac{0.89}{11.06}$ & & $-\frac{33}{2 .} \cdot \frac{73}{6}$ & & $\frac{8.01}{12.60}$ & & -19.94 & & $-\frac{95939.56}{11.69}$ & \\
\hline
\end{tabular}

$\mathrm{SV}$, sources of variation; DF, degrees of freedom; CV, coefficient of variation; ST, seed treatment; S, study areas (Barra Funda, Cândido Godói, and Tupanciretã); ${ }^{\text {ns }}$ non-significant; *significant at $\mathrm{p}<0.05$ using the F-test.

PH30DAS was highest in Barra Funda, and there were significant differences between the treatments only in Tupanciretã, where fungicide + Trichoderma spp. + Biozyme $^{\mathbb{R}}$ was more effective, and plant height was higher than that in the other treatments (Table 3). Mertz, Henning and Zimmer (2009) observed that the height of soybean plants obtained from seeds treated with different fungicides and Trichoderma-based bioprotective agents under field conditions was not significantly different at 28 DAS. However, shoot and root growth was comparatively higher in treatments with Trichoderma spp. in sunflower and soybean crops (GUARESCHI et al., 2012).

Table 3. Mean plant height at 30 days after sowing [DAS] (PH30DAS) and the number of pods per plant (NPP) in soybean seeds treated with chemical and biological inputs in the municipalities of Barra Funda, Cândido Godói, and Tupanciretã, Rio Grande do Sul, Brazil, in the 2010/2011 growing season.

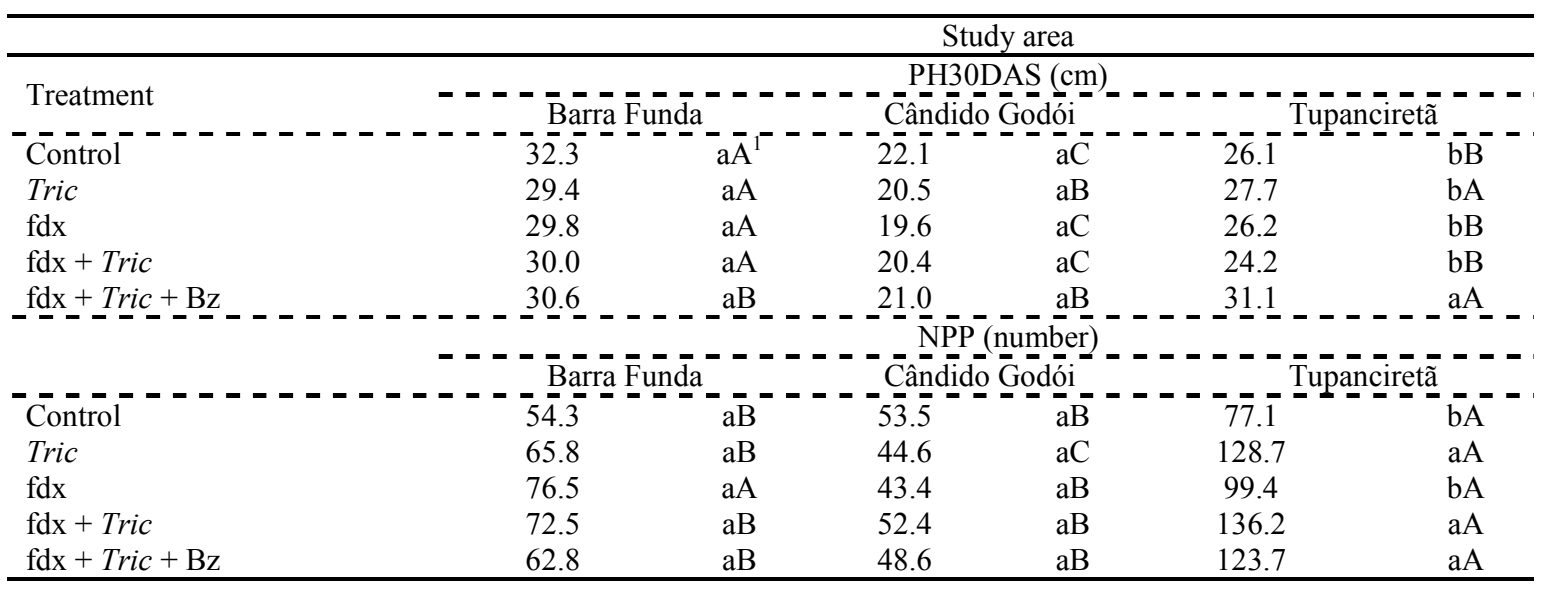

SA, study areas (Barra Funda, Cândido Godói, and Tupanciretã; C, control; Tric, Trichoderma spp.; fdx, fludioxonil; $\mathrm{Bz}$, Biozyme ${ }^{\mathbb{B}}$; ${ }^{1}$ The means followed by the same lowercase letter in each column and the same uppercase letter in each row were not different from each other using the Scott-Knott test at a level of significance of 5\%.

Harman et al. (2004) found that Trichoderma spp. increased the absorption of nitrogen, arsenic, cobalt, cadmium, chromium, nickel, lead, vanadium, magnesium, manganese, copper, boron, zinc, aluminum, and sodium. However, in most cases, the increase in the absorption of these elements was small in agricultural systems. Biozyme ${ }^{\circledR}$, which was used in combination with other control agents to treat soybean seeds, has been shown to increase the vigor of maize seedlings up to a dose of $10 \mathrm{~mL} \mathrm{~kg}^{-1}$ of seeds (NICCHIO et al. al., 2013).

There were significant differences in NPP between the treatments only in Tupanciretã, and the NPP in treatments with Trichoderma spp., fludioxonil + Trichoderma spp., and fludioxonil + Trichoderma spp. + Biozyme $^{\circledR}$ was increased by $67 \%, 77 \%$, and $60 \%$, respectively, relative to the control (Table 3). However, the NPP responded differently to treatments in each municipality and was significantly higher in Tupanciretã in all treatments relative to the other regions. Fungicides combined with biological control agents and/or growth stimulators can benefit soybean cultivation by reducing the risk of development of fungicide- 
resistant pathogens and broadening the control spectrum (PESQUEIRA; BACCHI; GAVASSONI, 2016).

There were no significant differences in NP1G and NP3G between the treatments (Table 1). This result is because this yield component is strongly affected by cultivars, which, to date, are selected to produce three eggs per pod (KRUTZMANN et al., 2013). However, the NP2G in treatment with Trichoderma spp. and Trichoderma spp. + fludioxonil was $23.8 \%$ and $22.4 \%$ higher than that of the control, respectively (Table 4).

Table 4. Mean number of pods with two grains (NP2G), number of filled grains (NFG), number of infected grains (NIG), and grain yield (GY) in soybean seeds treated with chemical and biological inputs in the municipalities of Barra Funda, Cândido Godói, and Tupanciretã, Rio Grande do Sul, Brazil, in the 2010/2011 growing season.

\begin{tabular}{|c|c|c|c|c|c|c|c|c|}
\hline \multirow{2}{*}{$\begin{array}{l}\text { Treatment } \\
\text { Control }\end{array}$} & \multicolumn{2}{|c|}{ - - - NP2G } & \multicolumn{2}{|c|}{ number } & \multicolumn{2}{|c|}{ NIG _ _ - } & \multicolumn{2}{|c|}{ 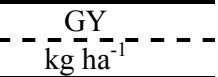 } \\
\hline & 37.0 & $\mathrm{~b}^{1}$ & 183.7 & $\overline{\mathrm{c}}$ & 29.3 & $\mathrm{a}$ & 2,461 & $\mathrm{~b}$ \\
\hline Tric & 45.8 & $\mathrm{a}$ & 195.8 & $\mathrm{~b}$ & 21.0 & $\mathrm{~b}$ & 2,451 & $\mathrm{~b}$ \\
\hline$f d x$ & 37.0 & $\mathrm{~b}$ & 201.4 & $\mathrm{a}$ & 20.3 & $\mathrm{~b}$ & 2,800 & $\mathrm{a}$ \\
\hline $\mathrm{fdx}+$ Tric & 45.3 & $\mathrm{a}$ & 201.4 & $\mathrm{a}$ & 20.2 & $\mathrm{~b}$ & 2,754 & $\mathrm{a}$ \\
\hline $\mathrm{fdx}+$ Tric $+\mathrm{Bz}$ & 35.5 & $\mathrm{~b}$ & 197.8 & $\mathrm{~b}$ & 21.3 & $\mathrm{~b}$ & 2,788 & $\mathrm{a}$ \\
\hline
\end{tabular}

C, control; Tric, Trichoderma spp.; fdx, fludioxonil; Bz, Biozyme ${ }^{\circledR} ;{ }^{1}$ The means followed by the same lowercase letter in each column were not different from each other using the Scott-Knott test at a level of significance of 5\%.

The control treatment presented a increase in the NIG when compared to the other treatments and a 8.8 decrease in the NFG relative to treatment with fludioxonil and fludioxonil + Trichoderma spp. (Table 4). This result is related to the lower incidence of foliar diseases and the lower percentage of defoliation of soybean plants when ST is performed (GOULART; ROESE; MELO, 2015) by increasing the production of photoassimilates and, consequently, grain filling.

The NFG was $8.8 \%$ higher in the treatments fludioxonil and fludioxonil + Trichoderma spp. than was that in the control. The NFG in treatments with Trichoderma spp. and fludioxonil + Trichoderma spp. + Biozyme $^{\circledR}$ was $2.8 \%$ and $1.8 \%$ lower than treatment with fludioxonil and fludioxonil + Trichoderma spp., respectively. In addition to the lower defoliation and lower incidence of diseases (GOULART; ROESE; MELO, 2015), the combination of a fungicide, Trichoderma spp., and Biozyme $^{\circledR}$ may have supplied the required micronutrients for plant development, which favored grain filling (AVELAR et al., 2011).

GY using Trichoderma spp. was not significantly different from that of the control.
Nonetheless, GY using a fungicide, fungicide + Trichoderma spp., and fungicide + Trichoderma spp. + Biozyme $^{\circledR}$ increased by $14 \%, 12 \%$, and $13 \%$, respectively, relative to the control (Table 4). This finding may be because chemical treatments provide greater protection to seeds and seedlings against the attack of plant pathogens (CONCEIÇÃO et al., 2014), favoring plant emergence and increasing GY. Although Trichoderma spp. alone did not increase GY, Görgen et al. (2009) observed the isolate 1306 of Trichoderma harzianum increased GY in soybeans.

There were no significant differences in the TGM in the presence or absence of chemical and biological treatment of soybean seeds. These results corroborate those of Goulart, Roese and Melo (2015), in which, in 2 years, ST with and without fluquinconazole did not affect the TGM regardless of whether fungicide was applied to soybean stems. However, in the present study, there were significant differences in the TGM between the municipalities, and the TGM was $6.1 \%$ and $8.4 \%$ higher in Tupanciretã than in Cândido Godói and Barra Funda, respectively (Table 5).

Table 5. Mean values of plant height at 60 days after sowing [DAS] (PH60DAS), number of pods with one grain (NP1G), number of pods with two grains (NP2G), number of pods with three grains (NP3G), number of filled grains (NFG), thousand-grain mass (TGM), and grain yield (GY) in soybean seeds treated with chemical and biological inputs in Barra Funda, Cândido Godói, and Tupanciretã, Rio Grande do Sul, Brazil, in the 2010/2011 growing season.

\begin{tabular}{|c|c|c|c|c|c|c|c|}
\hline Municipality & \begin{tabular}{c} 
PH60DAS \\
\hdashline $\mathrm{cm}$
\end{tabular} & $\mathrm{NP} 1 \mathrm{G}$ & $\mathrm{NP} 2 \mathrm{G}$ & NP3G & NFG & $\begin{array}{c}\text { TGM } \\
\mathrm{g}\end{array}$ & $\begin{array}{c}\mathrm{GY} \\
\mathrm{kg} \mathrm{ha}^{-1}\end{array}$ \\
\hline Barra Funda & $86.3 b^{1}$ & $3.8 \mathrm{~b}$ & $38.8 \mathrm{~b}$ & $23.4 \mathrm{~b}$ & $180.7 \mathrm{c}$ & $159.2 \mathrm{c}$ & $2,518 \mathrm{~b}$ \\
\hline Cândido Godói & $97.7 \mathrm{a}$ & $4.1 \mathrm{~b}$ & $28.9 \mathrm{c}$ & $15.6 \mathrm{c}$ & $190.9 \mathrm{~b}$ & $162.7 \mathrm{~b}$ & $2,617 \mathrm{~b}$ \\
\hline Tupanciretã & $96.0 \mathrm{a}$ & $8.7 \mathrm{a}$ & $52.7 \mathrm{a}$ & $51.2 \mathrm{a}$ & $216.5 \mathrm{a}$ & $172.6 \mathrm{a}$ & $2,818 \mathrm{a}$ \\
\hline
\end{tabular}

${ }^{1}$ The means followed by the same lowercase letter in each column are not different from each other using the Scott-Knott test at a level of significance of $5 \%$. 
In Tupanciretã, the soybean cultivar and treatments used were adequate to local conditions because there was an increase in PH60DAS, NFG, NP1G, NP2G, NP3G, TGM, and GY compared to the other two regions (Table 5). This difference in response to ST may be related to the edaphoclimatic conditions in each region. However, these differences were expected because of the agroclimatic zoning of each region.

\section{CONCLUSIONS}

The fungicide fludioxonil combined with the fungus Trichoderma spp. and the growth stimulator Biozyme $^{\circledR}$ is indicated for treating soybean seeds and increases crop development and yield.

Soybean development and grain yield responded differently to treatment with chemical and biological inputs, regardless of the study area.

\section{ACKNOWLEDGMENTS}

The authors are grateful to Dionas de Freitas Bock, Robson Antonio Botta, and Rodrigo Trindade Pinheiro (Universidade Federal do Pampa, Itaqui, RS, Brazil) for assisting with the implementation and execution of the field experiments.

\section{REFERENCES}

AVELAR, S. A. G. et al. Armazenamento de sementes de soja tratadas com fungicida, inseticida e micronutriente e recobertas com polímeros líquido e em pó. Ciência Rural, v. 41, n. 10, p. 1719-1725, 2011.

COMPANHIA

NACIONAL

DE ABASTECIMENTO - CONAB. Acompanhamento de safra brasileira: grãos. Safra 2018/19 Quarto levantamento, Brasília, 2019. 126 p. Disponível em: $<$ https://www.conab.gov.br/info-agro/safras/graos $>$. Acesso em: 30 jan. 2019.

CONCEIÇÃO, G. M. et al. Desempenho de plântulas e produtividade de soja submetida a diferentes tratamentos químicos nas sementes. Bioscience Journal, v. 30, n. 6, p. 1711-1720, 2014.

EMPRESA BRASILEIRA DE PESQUISA AGROPECUÁRIA - EMBRAPA. Sistema brasileiro de classificação de solos. 3 . ed. Rio de Janeiro, RJ: Embrapa Solos, 2013. 353 p.

ETHUR, L. Z. et al. Fungos antagonistas a Sclerotinia sclerotiorum em pepineiro cultivado em estufa. Fitopatologia Brasileira, v. 30, n. 2, p. 127 -
133,2005 .

ETHUR, L. Z. et al. Trichoderma asperellum na produção de mudas contra a fusariose do pepineiro. Scientia Agraria Paranaensis, v. 11, n. 4, p. 73-84, 2012.

GÖRGEN, C. A. et al. Controle do mofo-branco com palhada e Trichoderma harzianum 1306 em soja. Pesquisa Agropecuária Brasileira, v. 44, n. 12, p. 1583-1590, 2009.

GOUlART, A. C. P.; ROESE, A. D.; MELO, C. L. $P$. Integração do tratamento de sementes com pulverização de fungicidas para controle da ferrugem asiática da soja. Bioscience Journal, v. 31, n. 3, p. 737-747, 2015.

GUARESCHI, R. F. et al. Emprego de Trichoderma spp. no controle de Sclerotinia sclerotiorum e na promoção de crescimento vegetativo nas culturas de girassol e soja. Global Science and Technology, v. 5, n. 2, p. 1-8, 2012.

HARMAN, G. E. et al. Trichoderma speciesopportunistic, a virulent plant symbionts. Nature Reviews Microbiology, v. 2, n. 1, p. 43-56, 2004.

HENNING, A. A. et al. Importância do tratamento de sementes de soja com fungicidas na safra 2010/2011, ano de "La Niña". Londrina, PR: Embrapa Soja, 2010. 7 p. (Circular técnica, 82).

KASTER, M.; FARIAS, J. R. B. Regionalização dos testes de valor de cultivo e uso e da indicação de cultivares de soja - Terceira Aproximação. Londrina, PR: Embrapa Soja, 2011. 69 p. (Documentos, 230).

KRUTZMANN, A. et al. Palhadas de gramíneas tropicais e rendimento da soja no sistema de integração lavoura-pecuária. Bioscience Journal, v. 29, n. 4, p. 842-851, 2013.

MACHADO, D. F. M. et al. Trichoderma no Brasil: o fungo e o bioagente. Revista de Ciências Agrárias, v. 35, n. 1, p. 274-288, 2012.

MASTOURI, F.,; BJÖRKMAN, T.; HARMAN, G. E. Seed treatment with Trichoderma harzianum alleviates biotic, abiotic, and physiological stresses in germinating seeds and seedlings. Phytopathology, v. 100, n. 11, p. 1213-1221, 2010.

MERTZ, L. M.; HENNING, F. A.; ZIMMER, P. D. Bioprotetores e fungicidas químicos no tratamento de sementes de soja. Ciência Rural, v. 39, n. 1, p. 13-18, 2009.

NICCHIO, B. et al. Ácido húmico e bioativador no 
tratamento de sementes de milho. Journal of Agronomic Sciences, v. 2, n. 2, p. 61-73, 2013.

PANDOLFO, J. D. Associação de Trichoderma sp. e fungicidas no controle de Fusarium oxysporum f. sp. phaseoli. 2007. 67 f. Dissertação (Mestrado em Fitotecnia: Área de Concentração em Fitossanidade) - Universidade Federal do Rio Grande do Sul, Porto Alegre, 2007.

PAZINI, J. B. et al. Toxicidade de fungicidas ao Trichoderma spp. em sementes de soja. Revista Científica Rural, v. 15, n. 2, p. 95-102, 2013.

PESQUEIRA, A. S.; BACCHI, L. M. A.; GAVASSONI, W. L. Associação de fungicidas no controle da antracnose da soja no Mato Grosso do Sul. Revista Ciência Agronômica, v. 47, n. 1, p. 203-212, 2016.

R DEVELOPMENT CORE TEAM. R. A language and environment for statistical computing. rev. 3.2.0. Vienna: $\mathrm{R}$ Foundation for Statistical Computing. 2015. Disponível em: <http://rproject.org > . Acesso em: 10 ago. 2015. 